\title{
Research on the Cultivation of Applied Undergraduate Business and Trade Talent in Guangdong Based on New Business Form
}

\author{
Ming LUO \\ Department of Management \\ Guangdong University of Science and Technology, \\ 523083 Dongguan, Guangdong, China \\ E-mail:luoming8654@163.com
}

\author{
Fei WANG \\ Department of Management \\ Guangdong University of Science and Technology, \\ 523083 Dongguan, Guangdong, China \\ E-mail: 55833449@qq.com
}

\begin{abstract}
The purpose of this paper is to provide reference suggestions for the cultivation of applied undergraduate business and trade talent based on new business form, design "five in one" business and trade entrepreneurial talent training program, train their ability of applications and practice, extend the importance of practice in business and trade of new business teaching, so as to improve the key capability and core competition of the applied undergraduate business and trade talents.
\end{abstract}

Keywords-New Business Form; Business and Trade; Applied undergraduate; Talent Training

I. The New Business Form Poses A New CHALlENGE To The Cultivation OF Business TALENTS In GuANGDONG PROVINCE

Guangdong is located in the Pearl River Valley of the golden waterway, linking the regions to rivers and seas. The hinterland is vast, the geographical position is extremely superior, and it possesses the natural advantages of engaging in commerce and the trade through the world. Established, by commerce and trade, thrived due to commerce, it is the largest commercial and trade distribution center in China for thousands of years.

Adhere to the inheritance of tradition and innovation, the commerce and trade in Guangdong vigorously develop new forms of business and modern circulation, the level of development on commerce and trade has been greatly improved. Business and trade services have gone through hundreds of years of development in developed countries within 40 years, and are now at the forefront of innovation in international trade. Many latest international business formats such as brand flagship store, concept store, brand home and so on almost emerge at the same time with Europe and the United States.

In recent years, the development of business and trade is faced with many new situations, new problems, and new trends. For example, the total sales of commodities and the total retail sales of social consumer goods and the total volume of import and export trade continued to grow, but the growth rate slowed down; Innovative business and trade leaders and a variety of specialized technical personnel are relatively deficient; The management mode of traditional business and trade and commercial and trade mode are relatively single, the business circle, business enterprise and the operation phenomenon of homogenization in business form is more serious; The restriction of energy resources and ecological environment is strengthened, and the cost of commerce and trade increases rigidly, which makes the sustainable development of commerce and trade face many difficulties. The development of commerce and trade in the surrounding provinces and cities is rapid, the advantage of commercial and trade development is relatively weakened, and the pressure of development increased. The scale of citizens' outbound tourism and overseas consumption has gradually expanded, which has brought enormous impact to the development of consumer goods market and so on. These new trends, new problems and new situations in the development of business and trade are in urgent need of versatile business and trade talents. However, there is a big gap between the talent training mode of applied undergraduate colleges and the demand of commercial and trade talents at present. There is a scarcity of versatile talent capable of doing business and trade work.

Under the background of "Internet +", it is urgent for colleges and universities to seize the opportunity of the development of the times, to explore the suitable training mode of talents according to the characteristics of the demand for talents and the requirements of job responsibilities of the commercial and trade industries. Based on the requirement of capacity and quality of business and trade professionals in Guangdong Province the project put forward clear talent training goals, build a professional curriculum system, create high-quality teaching team and open campus productive training base, and actively promote the practical undergraduate business and trade talent training practice. 


\section{THE NEW BUSINESS FORM DEVELOPMENT OF GUANGDONG'S COMMERCE AND TRADE}

All through the year of 2017 , total retail sales of consumer goods was CNY 36.6262 trillion, an increase of 10.2\%.Among them, the retail volume of consumer goods above the quota is CNY16.0613 trillion, increase by $8.1 \%$, among which new retail development is very obvious.

Among them, the national online retail volume was $\mathrm{CNY}$ 7.1751 trillion, an increase of $32.2 \%$ over the previous year and 6 percentage points faster than the previous year. Among them, the online retail volume of real goods is CNY 5.4806 trillion, up $28 \%$, accounting for $15 \%$ of the total retail sales of social consumer goods. In the online retail sales of physical goods, the food, wear and use of commodities have increased by $28.6 \%, 20.3 \%$ and $30.8 \%$, respectively.

In the ranking of total consumption of e-commerce goods in all province, Guangdong consumers who is enthusiastic with "online shopping" won many "laureates. "Guangdong was ranked first in the online consumption among all provinces, the first in average urban consumption scale and the first in the number of e-commerce TOP100 cities. Meanwhile, the proportion of Guangdong's general trade increased steadily in 2017, achieving CNY 3.14 trillion of imports and exports, an increase of $14.3 \%$, and the import and export of cross-border e-commerce add up to CNY 44 billion 190 million, an increase of $93.8 \%$ compared with the same period last year, ranking the first in the country.

Innovate business development model, and stimulate the vitality of business development. Promote the integration of resources, such as online and offline business, brands, channels, customers and other resources, forming a fullchannel development model. Promote the traditional commercial enterprises rely on the offline network channel resources, commodity brands and service advantages, build their own online platform or use the third party platform to develop e-commerce, and achieve the complement and collaborative application of online and offline resources. To promote the cooperation of e-commerce enterprises with offline convenience stores and supermarkets, or to build their own offline service centers, to carry out the "online booking store and take from offline store" service, and to form a multilevel distribution network of regional distribution centers, transit distribution centers and community distribution service stations, Enhance the delivery service capacity of the last kilometer of logistics. Guide the commercial enterprises to expand the mobile Internet and the home Internet, realize the complementary advantages between the store end and PC, mobile phone, TV terminal; explore the new mode of allchannel integration and development, and inject new vitality into the commercial development of Guangdong.

At present, e-commerce is promoting the development of foreign trade to the direction of informationize, which opens up a new path for the sustainable development of foreign trade. Guangdong should seize the opportunity to encourage the development of a number of professional crossborder e-commerce platforms in the superior areas of the province, such as electronic products, household appliances, automobiles, and key high-tech products, so as to promote the docking of foreign trade enterprises with cross-border ecommerce platforms. Enhance the scale and influence of cross-border e-commerce platform. To support large foreign trade enterprises to use e-commerce to transform supply chain processes, to support small and medium-sized foreign trade enterprises to use third-party cross-border e-commerce platform to expand their business. At the same time, the establishment of cross-border e-commerce park, and establish strategic cooperation with domestic and foreign well-known cross-border e-commerce platform, to achieve resource sharing, improve market competitiveness, and promote the development of foreign trade enterprises.

\section{CHARACTERISTICS OF TALENT DEMAND FOR BUSINESS AND TRADE UNDER THE NEW BUSINESS FORM}

With the vigorous development of commerce and trade in recent years, it also gradually presents five new advantages of "multilateralism, directness, small batch, high frequency and digitization" which are not possessed by the traditional international trade. In terms of the definition, characteristics and trends of business and trade, its specific requirements for relevant personnel are as follows:

\section{A. Wide Caliber}

It not only includes the necessary knowledge of foreign trade, but also involves professional knowledge of electronic commerce, such as online store opening, product exposure, online marketing promotion, operation, business communication, order processing, documentary shipping, data analysis, etc. It also needs good foreign language skills, communication skills, cross-cultural communication skills and necessary cultural literacy. In addition, we also need to be familiar with various import and export modes of business and trade, such as B2B, B2C, C2C, C2M, etc.

\section{B. Multiple Skills}

It needs relevant talents to master foreign trade skills, electronic commerce skills, the skill of employing electronic commerce tools, product design skills, professional comprehensive literacy and so on. In addition, foreign language skills are essential. Otherwise it will be difficult to achieve cross-border business.

\section{High Compounding:}

It not only includes international trade, electronic commerce, business English and other related professional content, but also involves computer technology, industrial design, photography and other majors.

The particularity of the demand for business and trade talents determines that the cultivation of talents must be rooted in applied undergraduate colleges. As the practical practitioners of applied undergraduate colleges, we should achieve accurate positioning, wide caliber, and better combination. The orientation here means that colleges and universities should be clear about what kind of commercial and trade talents to train. Whether they should train junior talents who acquire only practical operating ability, or train middle-level or high-level talents who knows operation, 
understand the management and proficient in foreign language, specialized in cross-cultural communication; Broad-caliber refers to the cultivation of cross-border talent who must be proficient in a variety of skills, and competent to deal with various problems as a versatile talent ;Compounding is that, based on the characteristics of business and trade, the various professions and knowledge must be "seamlessly connected".

\section{THE TRAINING MECHANISM OF APPLIED} UNDERGRADUATE BUSINESS AND TRADE TALENTS UNDER THE NEW BuSINESS FORM

According to the analysis of entrepreneurial talents requirement on business and trade, and the research of professional adaptability of domestic and foreign scholars in recent years, The improvement of vocational adaptability needs to carry on the comprehensive reform from the education goal, the education content, the teaching pattern, the school management and so on, the cultivation of core ability of applied undergraduate electronic commerce entrepreneurial talents can be carried out through the following measures:

\section{A. Designing "five in one" Business and Trade Entrepreneurial Talent Training Program}

In order to improve students' practical skills, make full use of various practical teaching resources, and insist on the close integration of talent training with the development of business and trade, This paper designs a "five-in-one" progressive business and trade talent training scheme based on the theory of "theoretical teaching-cognitive demonstration-verification simulation-virtual operation-reality training".

Innovative business and trade training programs are divided into modules of business and trade ability, electronic commerce basic, business English, network marketing, graduation and so on to carry on the theory and practice teaching, with the training of ability and quality as the core. To break through some institutional constraints of talent training in colleges and universities, and to design the training scheme of business and trade talents according to the demand of business and trade talents, so that the ecological alliance system of training business and trade talents can not only meet the needs of enterprises, but also create the needs of enterprises. Finally realizes the win-win goal.

\section{B. Constructing the "Ecological Alliance of School, Business and Enterprise" for Talent Training in Business and Trade}

Business and trade are originally a very large ecosystem, and it is very difficult to achieve the corresponding personnel training by colleges and universities alone. Therefore, the establishment of business and trade entrepreneurial talent training schools, industries, "ecological alliance" of enterprises is the inevitable trend of development. With the China Foreign Trade and Economic Cooperation Enterprise Association, Guangdong Electronic Commerce Association, Alibaba, DHgatet, Amazon and other industry associations and famous business and trade platforms forming a business and trade entrepreneurial talent training "school and enterprise ecological alliance" ,we can organically combine business and trade talents' theoretical knowledge learning, industry practice cognition, and business innovation, etc. by integrating the relevant commercial and trade business resources in the society and fully mobilizing many effective factors in the ecosphere, . Through the cooperative operation of talent training ecological alliance, the learning and application of knowledge is closely combined with business innovation. Try to set up "teaching factory" in order to ensure that students can really learn, apply and innovate the knowledge of business and trade, and promote the combination of the theory of electronic commerce and the practice of development.

\section{Establishing the "Creation Space" for the Growth of Business and Trade Entrepreneurial Talents}

In addition to the establishment of traditional commercial and trade experimental centers, training centers or research centers, universities can also try to establish the "Maker space" between business and trade, and build a platform for students from curriculum theory knowledge, practice, and professional apprenticeship to comprehensive training, innovation and entrepreneurship, so as to fully realize the docking of industry and learning. Students are encouraged to participate in Alibaba's Business and Trade Talent Certificate and Trade account Registration in DHgate Business, in addition to their basic business and trade knowledge and basic operational skills. And relying on the educational and innovative resources of the ecological alliance, and through multi-party cooperation, to provide a certain innovative platform for business and trade talents. To help some students with business and trade entrepreneurial dreams to actively participate in the statesponsored development strategy of "greater maker can start his business, and thousands of makers can achieve innovation".

\section{Further Improving the Construction of Dual Teachers}

Focus on enhancing the practical teaching ability of the professional teachers of business and trade; Send teachers to enterprises and institutions to promote their practical application .By combining the actual situation of practical enterprises to prepare cases, encouraging teachers to apply for horizontal projects, schools are expected to support in the supporting funds ; At the same time, in the commercial and trade training practice base of Dongguan DHgate Heguang Information Technology Co., Ltd., , Employ enterprise managers as part-time teachers to participate in teaching, internship, graduation design and employment guidance.

\section{E. Reforming and Innovating the Examination Method and Stressing the Evaluation of Application Ability}

The assessment of curriculum has changed from paying attention to the key points of knowledge to the evaluation of outstanding ability of application and innovation. The purpose of the examination has changed from the evaluation of knowledge to the ability of flexible use .The form of examination is from closed examination to open book, thesis and defense, case analysis, investigation report, planning project book and so on. The skill assessment emphazis the process, solution design, curriculum design, practical creation and other forms. It strengthens the rating of students' 
application ability and leads students to improve their consciousness of application ability.

\section{F. Third party Education Certification}

The professional certification system is the ability standard system set up by the trade association to guide the curriculum setting of colleges and universities. The curriculum setting corresponds with the ability standard system in colleges and universities, and the industry association provides the organization security system to test its responsiveness. The foundation of the professional certification system is the professional competence standard of the industry, and SB/T 11089.2014, the industry circulation standard of the Ministry of Commerce in which our hospital is currently participating. "Norms of nurturing competence and evaluation for specialties of trade and commerce at vocational colleges " has been issued, through the third party certification industry association, further test our business and trade professional entrepreneurship core competence training quality.

The professional certification system is the ability standard system set up by the trade association to guide the curriculum setting of colleges and universities. The curriculum setting corresponds with the ability standard system in colleges and universities, and the industry association provide the organization security system to test its responsiveness. The foundation of the professional certification system is the professional competence standard of the industry, and the industry circulation standard of "Norms of nurturing competence and evaluation for specialties of trade and commerce at vocational colleges "(SB/T 11089.2014) has been issued by the Ministry of Commerce currently, through the third party certification industry association, further test our business and trade professional entrepreneurship core competence training quality.

\section{CONCLUSION}

In the "Internet plus" setting, between business and trade appeared new forms of new retail and new trade, It period presented a new challenge to applied undergraduate business and trade talent training based on new business form. The future development of business and trade industry relies on the cultivation of innovative talents with international view and long-term strategic aims. As a result, policies are required to go along with time, it is necessary to adapt to new forms person with ability of business \& trade class and the reforming of talents training mode keeping up with the times.

\section{ACKNOWLEDGMENT}

Fund:

(1) Higher Education Reform Project of undergraduate Colleges and Universities in Guangdong Province [2016]236. (569).

(2) Pilot project of professional comprehensive reform in Guangdong University of Science and Technology [2015] 48. (1501001)

\section{REFERENCES}

[1] Jack Ma The electronic commerce will disappear, "five new" will subvert traditional industries [J]. Informatization Construction, 2016(11):18-21

[2] GE forms new downstream business [J]. World Pumps, 2014, 2014 (3).

[3] Junxia Chen. Recognition of Application-oriented University Practice Teaching [A]. Research Institute of Management Science and Industrial Engineering. Proceedings of 2017 2nd International Conference on Education \& Education Research(EDUER 2017)[C].Research Institute of Management Science and Industrial Engineering:,2017:4.

[4] WANG Yue, ZHANG Ruige. A Study on the Graduation Design of Business English Major in Application-oriented Universities under the Perspective of Language Economics [J].

[5] English on Campus, 2017 (52):16-17.Xue Lv. Study on Training Mode for Skill-oriented and Application-oriented Translation Talents under University-Enterprise Cooperation [A]. Research Institute of Management Science and Industrial Engineering. Proceedings of 2017 4th International Conference on Education, Management and Computing Technology(ICEMCT 2017) [C].Research Institute of Management Science and Industrial Engineering:,2017:5. 